\title{
REVIEW \\ Sustaining agri-food systems framed using soil security and education
}

\author{
Damien Field \\ The University of Sydney, School of Life and Environmental Science, Sydney Institute of Agriculture. \\ NSW, 2006.
}

\begin{abstract}
D. Field. 2020. Sustaining agri-food systems framed using soil security and education. Int. J. Agric. Nat. Resour. 249-260. Soil security is an emerging multidisciplinary concept that provides a framework with the potential to support the sustainability of the agri-food sector while simultaneously supporting the other functions that soil provides. This framework considers the biophysical, economic, and social dimensions that impact this multifunctional system. Particular attention is given to describing the impact of the recent development in assessing the soil's capacity and how it affects its function, assessed through its capability and condition. Progress in placing value on the functions of soil is explored, and the opportunity to increase connectivity between soil and end users is developed through multidisciplinary educational strategies. The perspectives provided here lead to a set of recommendations that will guide the development of future strategies, the pressing need for a set of measurable indicators, and the development of incentive schemes to secure the soil's ability to support agrifood systems and its other ecosystem functions.
\end{abstract}

Keywords: Natural capital, policy, reference state, social license, soil threats.

\section{Introduction}

Agri-food systems encompass a collection of subsectors, including crops, livestock, forestry, and fisheries (Steinfeld et al., 2019), and are generalized into land-intensive/extensive or capital/ labor-intensive systems. Capital-intensive systems are highly managed and coupled with highly modified environments, whereas land-extensive systems are typified by natural environments. Both systems impact soil and the ecosystem services that it provides (Robinson et al., 2014; Dominati et al., 2014). Securing these systems,

Received Ago 24, 2020. Accepted Oct 21, 2020.

Corresponding author: damien.field@sydney.edu.au in part, requires securing the soil that supports them, which is dependent on management by a skilled and educated workforce.

The ability of soil to produce food and sustain a healthy environment is determined by its capacity, which is limited by its capability and affected by its current condition (McBratney et al., 2019). The ability of the soil to store water, cycle nutrients and transform pollutants directly impacts food production (Lehmann \& Stahr, 2010). However, we now also expect soil to function as carbon storage, mitigating climate change, and a habitat and genetic sink for biodiversity (European 
Commission, 2006; Adhikari \& Hartemink, 2016; Amelung et al., 2020). Agricultural systems are now managed, monitored, and evaluated for their impact on the other functions that soil provides (Figure 1).

Soil security (McBratney et al., 2017) is a lesserknown challenge that is still very much confined to its discipline, yet without soil, there is no provision of food and ecosystem services (Holt et al., 2016; Wall \& Nielsen, 2012). The soil security concept is motivated by sustainable development and can secure our agri-food systems by ensuring that production is profitable while simultaneously meeting our aspirations to preserve water, the environment, and its biodiversity (Bennett et al., 2019). Some of the soil-related challenges that agri-food systems continue to face are predicated on the need to feed a growing world population. The increased intensification in food production has pushed soil to the limits, with estimates of 12 million hectares of soil being lost and degraded each year (Pozza \& Field, 2020). This has also resulted in deteriorating the soil's condition through the overexploitation of its nutrients, potentially resulting in crop failure and malnutrition (Goudie, 2013; Eld initiative, 2015; Pozza \& Field, 2020). An increasing urbanization of the population disconnects people from food production and understanding its impact on soil security, driven by a lack of care (Satterthwaite, McGranahan \& Tacoli, 2010).

The globally agreed aspirational sustainable development goals (SDGs) recognize that the future needs of the global population are dependent on creating strong, healthy agri-food systems as well as protecting and sustaining a healthy environment. Bouma (2019) identifies that unlike other disciplines that contribute to agri-food systems, such as agronomy,
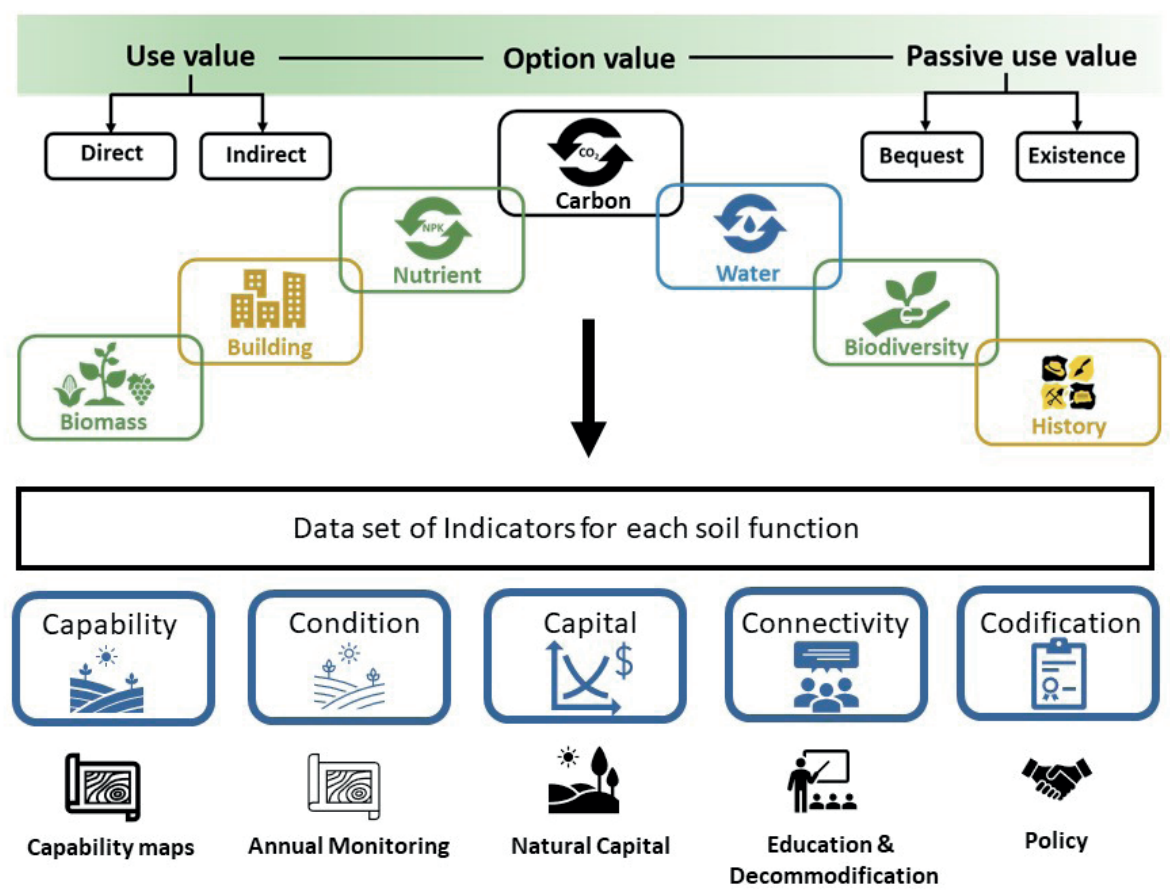

Figure 1. Schematic illustrating the interconnections of the seven soil functions assessed using yet-to-be-agreed-upon indicators providing data for evaluation using the 5 C's of soil security. The outcomes of this evaluation will be shared through capability mapping and annual monitoring, valuing natural capital, continued education and connecting the community through a social license, and policy interventions to protect vulnerable soil. The seven soil-specific functions are generally aligned with their contribution to each of the values determined through natural capital of use, option, and passive values. 
climatology, and hydrology, soil is not explicitly mentioned in the aspirational sustainable development goals (SDGs). The soil security concept has explicitly identified where soil contributes to these goals (Keestra et al., 2016; Bennett et al., 2019; Pozza \& Field, 2020), in particular, Zero Hunger (SDG2.4), Good Health (SDG3.9), Clean Water and Sanitization (SDG's 6.4, 6.6), Climate Change Policy (SDG13), and Life on Land (SDG's 15.3, 15.9) (Bouma et al., 2019; Pozza \& Field, 2020). Soil can be used to functionally connect these SDGs in a comprehensive, systematic approach by assessing the opportunity, value, and management of the challenges being addressed (Bouma et al., 2019).

Soil is a finite resource. It has long been reported that mismanagement has occurred due to it being undervalued or a lack of knowledge or care. The immediate response is the development of regulations to overcome this lack of integration (Pozza \& Field, 2020). Soil security provides a multidimensional strategy taking into account the balance of social, economic, and biophysical attributes (Bennett et al., 2019). The first proposal of the five security dimensions, capability, condition, capital, connectivity, and codification, was made by McBratney, Field \& Koch (2014); it is summarized in Table 1 and illustrated in Figure 1. There have been developments in the evaluation of the soil's capacity and complexity in evaluating its contribution to capital, which will be addressed here.

Farm and land managers in agri-food systems rely both on tacit and explicit knowledge (Par- minter \& Neild, 2013), and the advice provided by 'knowledge brokers' ensures that the latest soil management options are shared (McBratney, Koppi \& Field, 2016; Field et al., 2019). Through this Managers could be exposed to innovation by being well connected through their social and expert networks, which further enables knowledge sharing and capability building. experience, explicit knowledge will become part of their longer-term tacit knowledge (Parminter \& Neild, 2013). Soil security, through its connectivity framework, reimagines education with the promise of a future improvement of agri-food systems by producing land managers that contribute to knowledge networks and support farmers. Once again, the multifunctional nature of soil, beyond just producing food, needs to be recognized in the modern soil science curriculum (Havlin et al., 2010; Field et al., 2017; Baveye, Baveye \& Gowdy, 2016; Bouma, 2019), as is the need to work with those in socioeconomic disciplines (Bouma, 2019). This would mean developing an understanding of the role of soil in providing soil functions and ecosystem services. For example, clarifying the indicators of change and, more importantly, work within a framework that can advise on how changes in a soil function of interest will impact other functions that it provides.

This review provides a perspective and an update on the opportunity for soil security to provide a framework to secure soil-supporting agri-food systems and maintain environmental health. This includes advances in new assessment protocols

Table 1. Characteristics of each of the five soil security dimensions (Field, 2017; McBratney et al., 2019).

\begin{tabular}{|c|c|}
\hline Dimension & Description \\
\hline Capability & $\begin{array}{l}\text { Determines the reference state and is a measure of the biophysical ability of soil to carry out a function. This } \\
\text { dimension reflects change over geological timescales and can be thought of as analogous to 'genosoils'. }\end{array}$ \\
\hline Condition & $\begin{array}{l}\text { Measures the ability of soil to carry out functions, reflects the soil's response to management and is analogous } \\
\text { to 'phenosoils'. Collectively, with a soil's capability, characterizes the soil's capacity. }\end{array}$ \\
\hline Capital & $\begin{array}{l}\text { Affords the production and human-demanded function and attendant ecosystem services. The larger the value } \\
\text { is, the greater the attention for those functions and the role and importance of soil in social policy and the } \\
\text { economy. }\end{array}$ \\
\hline Connectivity & $\begin{array}{l}\text { Between the soil and those who want to use its products and services. The greater the formal recognition by } \\
\text { society of soil is, the higher protection should be afforded to continue its functions. }\end{array}$ \\
\hline Codification & $\begin{array}{l}\text { The governance of the soil through public regulation of its use, activities or through private regulation } \\
\text { awarding environmental sustainability accreditation and certification schemes. }\end{array}$ \\
\hline
\end{tabular}


for mapping the soil's capacity and the ongoing complexity in agreeing on valuing its capital contribution. While changes continue in recognizing soil in codification, the way soil security reimagines education and produces system thinkers with solid discipline knowledge will be paid particular attention.

\section{Capacity: the need for a reference state}

The capacity of soil to support agri-food systems is dependent on securing the soil's capability and its ongoing condition. The condition of the soil refers to changes in soil compared to a reference state (McBratney et al., 2019). There have been several concepts that are analogous to the soil's condition, including soil quality (Karlen et al., 2001) and soil health (Doran, 2002). As implied by Sojka, Upchurch \& Borlaug (2003), these terms remain deficient, as they do not make an explicit statement with regard to a reference state. This reference state is characterized by soil properties that reflect geological timescales rather than human management timescales, which better reflect the soil's condition.

The first regional mapping of the soil's capability and condition was published by Kidd et al. (2018) for the state of Tasmania, Australia. This undertaking demonstrated that digital soil mapping and assessment approaches could produce a detailed mapping in two dimensions using $80 \mathrm{~m}$ pixels. The determination of capability was similar to historical approaches of developing land capability mapping where the potential utility of the land is used to develop criteria used in land use planning. For example, the Food and Agriculture Organisation of the United Nations (FAO) land evaluation in dryland agriculture, forestry, irrigated agriculture, grazing, and steep lands (McBratney, Field \& Koch, 2014). The approach by Kidd et al. (2018) contributes to a history of land capability mapping, such as the LECS system (Elberson \& Siderius, 1990), and expert systems, such as ALES (Rossiter, 1990). The integration of biophysical and economic disciplines has also been achieved through frameworks such as SOLUS (Bouman et al., 1999). As queried by McBratney, Field \& Koch (2014), capability asks, "what function can this soil perform and in doing so what can it produce (support)". Reflecting on this thought, the question now to ask is 'what function', taking into account that every pedon is multifunctional, and the prioritization of one function, e.g., for agri-food systems, will impact the provision of the other 6 recognized overarching soil functions (Figure 1). Therefore, there is a need to identify soil change in agri-food systems, which requires a local independent representative soil, i.e., a reference state.

The recent advances in the allocation and mapping of the soil's capability, with a reference state, and changes in the local conditions are known as genosoils and phenosoils, respectively. Huang et al. (2018) developed a protocol for mapping genosoils and their related phenosoils over a pedologically diverse area. Significantly, this mapping of related profiles enabled the amount of soil change to be mapped and compared to their original genosoils in response to different land uses. Using this approach, McBratney et al. (2019) developed a protocol to evaluate and assess the amount of change in the soil's condition (phenosoils) compared to its capabilities (genosoils), which importantly provides the first approximation of an analytical framework to assess the soil's capacity to undertake each of its functions. Kidd et al. (2015 \& 2018) state that it is possible to identify a set of indicators that can be used to assess the capability and condition of a soil and how they affect soil function and develop an agreed set of indicators that can be used for all soil functions in the next challenge. These future indicators may be shared or unique to each of the seven functions, and the critical values may be regionally specific. For the agrifood sector, many of the indicators to assess the capability of soil and its current condition are established, as demonstrated by the capability, condition, and versatility maps produced by Kidd et al. (2015 \& 2018). 


\section{Capital: valuing soil}

The capital dimension of soil security is concerned with valuing soil to improve its security. Placing a value on 'things' that contribute to human well-being will avoid neglect and omission from any decision process (Robinson et al., 2009; McBratney, Field \& Koch, 2014; Field et $a l ., 2017)$. This value has been primarily derived from economic or monetary value. Generally, value can be derived from the 'use' of the goods or services the soil provides or accounting for those not directly derived from it, nominated as 'passive' values (Figure 1). A third category describes the value realized by the future preservation of a resource, i.e., the 'option' value. While there is no unequivocal agreement on these categories, the 'use' value is also assessed as a 'direct' economic value (Davidson, 2013), where goods and services interact directly, versus an 'indirect' value, which is often associated with regulating services provided by nature (Bruere et al., 2012). The valuing of goods and services that the individual never experienced or preserved for future generations is known as 'existence' and 'bequest' values, respectively.

There is still no global agreement on how to account for these values (Brown, Bergstrom \& Loomis, 2007; McBratney et al., 2012), and some suggest that it is not possible, except at a very local scale (Baveye, Baveye \& Gowdy, 2016). Life cycle analysis has been used to identify surrogates for assessing the impact on soil resources, including the loss of soil conditions with the application of agri-food management strategies (Notarnicola et al., 2012; Fagioli et al., 2017). Some studies have considered the loss or degradation of topsoil, the replacement of this soil, or the loss of productivity as a surrogate to measure the value provided by soil (Almansa, Calatrava \& Martinez-Paz, 2012; Telles et al., 2013). Proxies such as gross margins have been used to demonstrate the value that soil has supported (Kidd et al., 2015), and more comprehensive studies have focused on replacement costs to overcome soil nutrient loss and repair physical degradation (Dominati et al., 2014). Resource conservation, as an account in the value chain of agri-food systems, is another means to assess the value of soil. This has included the areal extent of agricultural production systems, including regenerative, organic, conservation, and conventional systems, as a surrogate for protecting the soil. Alternatively, yield has been used as a surrogate to assess the consumptive impact on soil fertility and loss of carbon (Fagioli et al., 2017).

Commonly associated with high-value crops, such as wine production, de-commoditization is an approach that has potential in the agri-food sector to secure soil. This approach refers to the segregation of products at the source and their tracking through the supply chain to the consumer (Bennett et al., 2019). This is based on gaining consumer confidence that the product was produced in a particular manner and/or contributes to ecosystem services (e.g., produces a carbon offset), thereby developing a social license that the customer is willing to pay more. The development of blockchain technologies and sensor technologies is enabling this approach to grow.

The multifunctionality of soil supporting agri-food systems and producing other ecosystem services collectively bring value. While gross margin analysis provides an indication of the value of goods produced from an area of soil (Kidd et al., 2015), it does not capture the value of the other functions that soil provides and therefore underestimates the value of the soil's natural capital.

Ideas around economies where resources, inputs, and waste are reused, replaced, recycled, or repurposed are put forward as a circular economy (Geissdoerfer et al., 2017; Lal et al., 2020) and are increasingly discussed as food-system and waste management strategies. Management options identified as conservation agriculture and regenerative agriculture look at the adaption of natural cycles emulating natural systems to maintain soil function (Lal et al., 2020). Soil management for agri-food systems includes 
increased value through the efficiency of using waste as nutrient streams. This also includes reclaiming the value of the soil by repairing and repurposing 'brownfields' and the redesign of cities to include urban agriculture, increasing people's connectivity (Pozza \& Field, 2020). The notion of willingness to pay (WTP) is an approach adopted to determine the indirect value placed on soil functions (Ryan \& Spash, 2011). This can be determined by surveying individuals or groups, where groupthink tends to moderate a price that is a better predictor than that determined by individuals. A remaining challenge is the agreement on a set of indicators that translate the support value that soil provides across the suite of soil functions (Figure 1).

\section{Connectivity: different ways of knowing}

There is still a need to develop a soil curriculum that produces experts who can advance the discipline and explain its relevance in cognate disciplines. Equally, there is a need to develop individuals with social intelligence and soil knowledge that can advise the agri-food and environmental sectors (Bouma \& McBratney et al., 2013). The connectivity dimension of soil security identifies education as a primary focus to produce soil experts and ensure that the wider community has access to timely, relevant, and contextual soil knowledge (Field, 2019). This will involve relying on explicit soil knowledge that needs to be integrated with the tacit knowledge of those engaged in the agri-food system. This requires a process of consultation and reflection (Rolfe, Freshwater \& Jasper, 2001) to understand what knowledge and skills are shared through teaching and recognizes that decisions may be relativistic (Bouma et al., 2011). Field (2019) recognized this separation of explicit knowledge to train experts, i.e., those who 'know' soil (Type C), and those who deliver contextually relevant knowledge that can integrate with the tacit knowledge, ethics, and values of the end user (Nowotny et al., 2001; Robertson et al., 2014; Kidd et al., 2018), described as people who 'know of' (Type B) soil.

As illustrated in Figure 2, the type B learner will have enough soil knowledge to understand the soil principles and processes to establish how these connect with the soil issues faced by the agri-food sector. If required, they can connect with the type $\mathrm{C}$ learner if a deeper or more complex understanding of soil is required (Figure 2). The conceptual framework for developing these learning environments is fully described in Field et al. (2017), and examples are provided in Hartemink et al. (2014). Practically, these learning environments engage with real-world problems that are multidisciplinary in nature. Problems that involve stakeholders from the agri-food sector will be more authentic and can introduce the economic and social dimensions that need to be considered when arriving at better or worse solutions (Bouma et al., 2011). The learners will gain skills in sharing knowledge in a professional environment, contextualize their academic learning of the soil, and be exposed to workplace culture (Field et al., 2017). The learning is deepened further if the solution that the students provide is partially or fully adopted by the industry (Figure 2).

There are some key principles that will guide the future of this educational approach, which are outlined in detail in Field et al. (2020). Regarding knowledge, it needs to be recognized that soil is part of an integrated system and is multifunctional. Fully analyzing and evaluating the role of soil and possible management strategies will require connecting this soil knowledge with other disciplines to demonstrate:

a) its contribution to these complex systems,

b) evaluate the efficacy of soil management options compared to others, and

c) ensure that the soil's agri-food function's improvement does not significantly degrade the other 


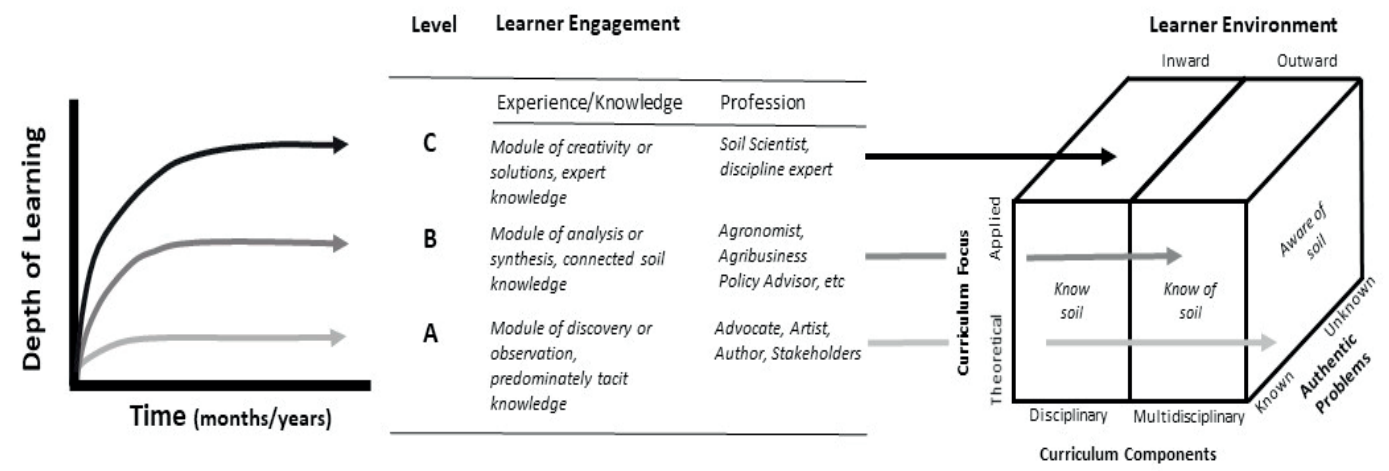

Figure 2. Illustration of the relationship between the type of learner, (A) aware of, (B) know of, and (C) Know, of the discipline of soil science illustrated with the level of experience and types of professions. Each of the learner types is then aligned with the expected teaching environment using the Teaching-Research-Industry-Learning Nexus (TRIL) described in Field et al. (2017) and modified from Field (2020).

functions it provides, resulting in its deterioration or in unintended consequences.

As described earlier, exploring the opportunity for learners to evaluate soil in other cognate disciplinary or multidisciplinary environments is crucial, as is the need to recognize the experiential, or tacit, knowledge of each of the learners in that environment. Collective reflection by all learners will result in a more comprehensive and deliberated solution.

\section{Codification - when all else fails}

This problem dimension acknowledges that soil will need to be secured through government policy and regulation. These policies are often directed towards ensuring environmental quality and the soil functions that impact this, e.g., regulating water and nutrient cycles, storing carbon, and protecting biodiversity (Figure 1). Several reviews have identified national and international policies related to soil, and their security is summarized in Field et al. (2017). More recently, Pozza and Field (2020) proposed a set of interactions of the soil security dimensions with food systems. It is clear that the availability of food and the food system's stability are dependent on soil policies. Previously, land suitability guided policy to address competing interests and the use of soil for food production. Advances in measuring and assessing soil capacity using the two soil security dimensions (McBratney et al., 2019) enable stakeholders and policy makers to assess the versatility (Kidd et al., 2015) of an area of soil. Through dialogue and cooperation, they can make fairer decisions on soil use and prevent negative impacts (Pozza $\&$ Field, 2020).

Looking towards 2030, Morgan et al. (2017) lists a set of goals where codification will contribute to securing soil and support for its functions (Figure 1). The case has also been made by Bennett et al. (2019) to develop policy instruments that monitor, account and report soil change, and to be included in evaluating the 'state of the nation' reporting, e.g., System of Environmental Economic Accounting (https:// seea.un.org/). The need to pay food producers to ensure the maintenance of the other soil functions that support ecosystem services has also been included (Figure 1). Internationally, there have been recent calls to ensure that soil is accounted for in support of the SDGs (Bouma, 2019b) and in the recent proposal of missions, driving the Horizon Europe 2021-2027 programs of protection and health (Horizon Europe, 2020 - https://ec.europa.eu/info/horizon-europe_en). This continued policy response to securing soil 
provides a roadmap that intersects the science of soil with the socioeconomic dimensions of soil security, where capability and condition provide the data and evidence, removing speculation when evaluating capital, connectivity and codification.

\section{Conclusions and Recommendations}

Utilizing soil security to sustain the agri-food sector will require developing a set of agreedupon indicators that enable the multifunctionality of soil to be assessed and mapped both spatially and temporarily. These indicators may be shared across or be unique to the functions that soil is expected to perform and are used to determine the soil's capacity (capability + condition) to support agri-food production and sustain the associated ecosystem services. The value of each of the functions needs to be assessed, and where the value is not realized, further education may be required (connectivity) or regulation to protect the resource (codification) may be needed (Figure 1). The following specific recommendations should guide future consideration.

The perspectives reviewed here outline recent advances that can be used to secure soil for the agri-food sector and environmental health. The newly proposed soil capacity mapping has yet to be assessed more widely, but the map products show potential for communicating soil capacity, which can be assessed for each of the soil functions, including food production. There remains an ongoing debate about valuing soil, but reimagining education, such as soil security as a multidisciplinary concept, will reconnect soil and the opportunity to increase people's willingness to care.

To realize this, the following recommendations are proposed for immediate action:

a) Establish an agreed mapping approach based on the capacity mapping developed by Mc-
Bratney et al. (2019) to establish capability (reference states) maps (Figure 1) and their associated phenosoil (condition) maps to illustrate soil change in response to land use. This can be further used to develop a national land capability statement produced across scales that underpins a national soil account (Bennett et al., 2019). This can be supported by regular evaluation and mapping of the soil's condition using an agreed-upon set of multifunctional indicators that support the agri-food sector.

b) Use the capability and condition maps to develop strategies that limit land expansion for agri-food production, protect the land to support other soil functions, optimize crop yields by matching to soil capabilities and conditions, and use precision agriculture type approaches to put the right amount of fertilizer in the right place at the right time.

c) Identify novel land management strategies to improve the soil condition relative to its capability and, in doing so, maximize the impact across the soil functions and protect soils that are identified as vulnerable. This is supported through the pursuit of education strategies based on multidisciplinary approaches to advising on management options.

d) Develop incentives to reward individuals through government credits and/or encourage, where possible, decommodification to support best management practices ensuring that soil supports agri-food and other soil functions. This requires the identification of indicators to be measured and monitored (Figure 1).

\section{Acknowledgements}

This manuscript summarises the authors' intended contribution at the Workshop on 
Challenges for Agroecology Development for the Building of Sustainable Agri-Food Systems (CRP), which was due to take place at the Faculty of Agricultural Sciences, University of Chile, Santiago de Chile, on 11-13 November 2019, and which was sponsored by the OECD Co-operative Research Programme: Biological Resource Management for Sustainable Agricultural Systems. Although due to the circumstances the workshop did not take place as a physical meeting and contributions intended to be supported by the OECD CRP are published in this Thematic Issue.

\section{Disclaimer}

The opinions expressed and arguments employed in this manuscript are the sole responsibility of the authors and do not necessarily reflect those of the OECD or of the governments of its Member countries. The opinions expressed and arguments employed in this manuscript are the sole responsibility of the authors and do not necessarily reflect those of the OECD or of the governments of its Member countries.

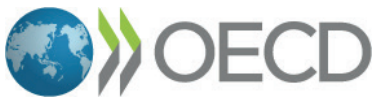

\title{
Resumen
}

\begin{abstract}
D. Field. 2020. Mantenimiento de sistemas agroalimentarios enmarcados mediante la seguridad y la educación del suelo. Int. J. Agric. Nat. Resour. 249-260. La seguridad del suelo es un concepto emergente y multidisciplinario que proporciona un marco teórico con el potencial de respaldar la sustentabilidad del sector agroalimentario y a su vez las otras funciones que proporciona el suelo. Este marco teórico considera las dimensiones biofísicas, económicas y sociales que impactan este sistema multifuncional. Se presta especial atención a describir el impacto del desarrollo reciente sobre la evaluación de la capacidad del suelo y cómo su función se ve afectada, a través de una evaluación de su capacidad y condición. Se explora el progreso en la puesta de valor de las funciones del suelo y se presenta la oportunidad de aumentar la conectividad entre el suelo y sus usuarios finales a través de estrategias educativas multidisciplinarias. Las perspectivas aquí proporcionadas conducen a un conjunto de recomendaciones que guiarán el desarrollo de estrategias futuras, así como de la urgente necesidad de indicadores medibles y de sistemas de incentivo para asegurar la capacidad del suelo para mantener sistemas agroalimentarios $\mathrm{y} / \mathrm{u}$ otros ecosistemas.
\end{abstract}

Palabras clave: Amenazas al suelo, capital natural, estado del arte, licencias sociales, políticas públicas.

\section{References}

Adhikari, K., \& Hartemink, A.E. (2016). Linking soils to ecosystem services-A global review. Geoderma, 262:101-111.

Almansa, C., Calatrava, J., \& Martinez-Paz, J.M. (2012). Extending the framework of the economic evaluation of erosion control actions in Mediterranean basins. Land Use Policy, 29:294-308.

Amelung, W., Bossio, D., de Vries, W., KögelKnabner, I., Lehmann, J., Amundson, R., Bol,
R., Collins, C., Lal, R., Leifeld, J., \& Minasny, B. (2020). Towards a global-scale soil climate mitigation strategy. Nature Communications, $11: 1-10$.

Baveye, P.C., Baveye, J., \& Gowdy, J. (2016). Soil “ecosystem' services and natural capital: Critical appraisal of research on uncertain ground. Frontiers in Environmental Science, 4:1-49.

Bennett, J.M., McBratney, A.B., Field. D., Kidd, D., Stockmann, U., Liddicoat, C., \& Gover, S. (2019). Soil security for Australia. Sustainability, 11:3416. 
Bouma, J., Van Altvorst, A.C., Eweg, R., Smeets, P.J.A.M., \& Van Latestejin, H.C. (2011). The role of knowledge when studying innovation and the associated wicked sustainability problems in Agriculture. Advances in Agronomy, Academic Press, USA, 113:285-314.

Bouma, J., \& McBratney, A.B. (2013). Framing soil as an actor when dealing with wicked environmental problems. Geoderma, 200-201:130-139.

Bouma, J. (2019). How the soil security concept can pave the way to realizing some soil related UNSDG's. In A. Richer-de-Forges, F. Carré, A.B. McBratney, J. Bouma, D. Arrouays (Eds), Global Soil Security: Towards More Science-Society Interfaces. CRC Press. pp. 3-9.

Bouma, J., Montanarella, L., \& Evanylo, G. (2019). The challenge for the soil science community to contribute to the implementaions of the UN Sustainable Development Goals. Soil Use and Management, 35:538-546.

Brown, T.C., Bergstrom, J.C., \& Loomis, J.B. (2007). Defining, valuing and providing ecosystem goods and services. Natural Resources Journal, 47:329-376.

Davidson, M.D. (2013). On the relation between ecosystem services, intrinsic value, existence value and economic valuation. Ecological Economics, 95:171-177.

Dominati, E., Mackay, A., Green, S., \& Patterson, M. (2014). A soil-change based methodology for the quantification and valuation of ecosystem services from agro- ecosystems: A case study of pastural agriculture in New Zealand. Ecological Economics 100:119-129.

Doran, J.W. (2002). Soil health and global sustainability: Translating science into practice. Agriculture Ecosystems. \& Environment, 88:119-127.

ELD Initiative. (2015). Report for policy and decision makers: Reaping economic and environmental benefits from sustainable land management. Germany.

Elberson, G.W.W., \& Siderius, W. (1990). Experiences with FAO's land evaluation computer system (LECS) in different environments Transactions. 14th International Congress of Soil Science, Kyoto, Japan, 7, pp. 290-295.
European Commission (EC). (2006). Communication from the Commission to the Council, the European Parliament, the European Economic and Social Committee and the Committee of the Regions, Thematic Strategy for Soil Protection, COM231, Final Brussels; European Commission: Brussels, Belgium.

Fagioli, F.F., Rocchi, L., Paolotti, L., Slowinski, R., $\&$ Boggia, A. (2017). From the farm to the agrifood system: A multiple criteria framework to evaluate extended multi0funational value. Ecological Indicators, 79:91-102.

Field, D.J., Yates, D., Koppi, A.J., McBratney, A.B., \& Jarrett, L. (2017). Framing a modern context of soil science learning and teaching. Geoderma, 289:117-123.

Field, D.J. (2017). Soil Security: Dimensions. In D.J. Field, C.L.S. Morgan, A.B. McBratney (Eds), Global Soil Security. Progress in Soil Science, Springer International, pp. 15-26.

Field, D.J. (2019). Soil security to connectivity: The what, so what, and now what. In A C. Richer-deForges, F. Carré F, A B. McBratney, J. Bouma, D. Arrouays (Eds) Global Soil Security: Towards More Science-Society Interfaces. CRC Press. Pp. 91-98.

Field, D.J. (2020). Framing soil science education. In R. Takashi, L. Lal, R. Reyes Sánchez (Eds), Soil Science Education. A global perspective (in press).

Field, D.J., Brevik, E., Hirai, H., \& Muggler, C. (2020). Guiding the future of soil (science) education: informed Fby global experiences. In R. Takashi, L. Lal, R. Reyes Sánchez (Eds), Soil Science Education. A global perspective (in press).

Geissdoerfer, M., Savaget, P., Bocken, N.M.P., \& Hultink, E.J. (2017). The circular economy - A new sustainability prardigm? Journal of Cleaner Production 143:757-768.

Goudie, A.S. (2013). The Human Impact on the Natural Environment: Past, Present, and Future. Wiley.

Hartemink, A.E., Balks, M.R., Chen, Z-S., Drohan, P., van Rees, K., Schad, P., Schipper, L.A., Sonneveld, M., \& Walter, C. (2014). The joy of teaching soil science. Geoderma, 2017-2018:1-9. 
Havlin, J., Balster, N., Chapman, S., Ferris, D., Thompson, T., \& Smith, T. (2010). Trends in soil science education and employment. Soil Science society of America Journal, 74:1429-1432.

Holt, A.R., Alix, A., Thompson, A., \& Maltby, L. (2016). Food production, ecosystem services and biodiversity: We can't have it all everywhere. Science of the Total Environment 573:1422-1429.

Huang, J., McBratney, A.B., Malone, B.P., \& Field, D.J. (2018). Mapping the transition from preEurpean settlement to contemporary soil conditions in the Lower Hunter Valley, Australia. Geoderma, 329:27-42.

Karlen, D.L., Andrews, S.S., \& Doran, J.W. (2001). Soil quality: Current concepts and applications. Advances Agronomy, 74:1-39.

Kidd, D., Webb, M., Malone, B., Minasny, B., \& McBratney, A. (2015). Digital soil assessment of agricultural suitability, versatility and capital in Tasmania, Australia. Geoderma Regional 6:7-21.

Kidd, D., Field, D., McBratney, A., \& Webb, M. (2018). A preliminary spatial quantification of the soil security dimensions for Tasmania. Geoderma, 322:184-200.

Lal, R., Brevik, E.C., Dawson, L., Field, D., Glaser, B., Hartemink, A.E., Hatano, R., Lascelles, B., Monger, C., Scholten, T., Singh, B.A., Spiegel, H., Terrible, F., Basile, A., Zhang, Y., Horn, R., Kosaki, T., \& Sanchez, A.B.R. (2020). Managing Soils for Recovering from the COVID-19 Pandemic. Soil Systems, 4:46.

Lehmann, A., \& Stahr K. (2010). The potential of soil functions and planner-oriented soil evaluation to achieve sustainable land-use. Journal of Soil Sediments, 10:1092-1102.

McBratney, A.B., Minansy, B., Wheeler, I., \& Malone, B.P. (2012). Frameworks for digital soil assessment. In B. Minansy, B. P. Malone, A. B. McBratney (Eds), Digital soil assessment and beyond. Taylor and Francis Group. London pp. 9-14.

McBratney, A.B., Field, D.J., \& Koch, A. (2014). The dimensions of soil security. Geoderma, 213:203-213.

McBratney, A.B., Koppi, A., \& Field, D.J. (2016). Radical soil management for Australia. A re- junvination process. Geoderma Regional, 7:132-136.

McBratney, A.B., Field, D.J., Morgan, C.L S., \& Jarrett, L.E. (2017). Soil Security: A Rationale. In D.J. Field, C.L.S. Morgan, A.B. McBratney (Eds), Global Soil Security. Progress in Soil Science, Springer International, pp.3-14.

McBratney, A.B., Field, D.J., Morgan, C.L.S., \& Huang, J. (2019). On soil capability, capacity and condition. Sustainability, 11:3350.

Morgan, C.L.S., McBratney, A. B., Field, D.J., Koch, A., Bouma, J., \& Carre, F. (2017). Synthesis: Goals to achieve soil security. In D.J. Field, C.L.S. Morgan, A.B. McBratney (Eds), Global Soil Security. Progress in Soil Science, Springer International, pp. 457-462.

Notarnicola, B., Hayashi, K., Curran, M.A., \& Huisingh, D. (2012). Progress in working towards a more sustainable agri-food industry. Journal of Cleaner Production, 28:1-8.

Parminter, T., \& Neild, J. (2013). Just knowing: Tacit knowledge. Extension Farming Systems Journal, 9:231-239.

Pozza, L., \& Field, D.J. (2020). The science of soil security dan food security, Soil Security, 1, (inpress).

Rolfe, G., Freshwater, D., \& Jasper, M. (2001). Critical Reflection in nursing and the helping professions: a users guide. Basingstoke: Palgrave McMillan.

Robinson, D.A., Fraser, I., Dominati, E.J., Davidsdotti, B., Jonson, J.O.G., Jones, L., Jones, S B., Tuller, M., Lebron, I., Bristow, K L., Souza, D M., Banwart, S., \& Clothier, B.E. (2014). On the value of soil resources in the context of natural capital and ecosystem service delivery. Soil Science Society America Journal, 78:685-700.

Rossiter, D.G. (1990). ALES: a framework for land evaluation using a microcomputer. Soil Use Management., 6, pp. 7-20.

Ryan, A.M., \& Spash, C.L. (2011). Is WTP an attitudinal measure? Empirical analysis of the psychological explanation for contingent values. Journal of Economic Psychology, 32:674-687. 
Satterthwaite, D., McGranahan, G., \& Tacoli, C. (2010). Urbanization and its implications for food and farming. Philosophical Transactions of the Royal Society B: Biological Sciences, 365:2809-2820.

Sojka, R.E., Upchurch, D.R., \& Borlaug, N.E. (2003). Quality soil management or soil quality management: Performance versus semantics. Advances in Agronomy, 79:1-68.
Telles, T.S., Falci Dechen, S.C., Antoniode Souza, L.G., \& Guimaraes, M.D.F. (2013). Valuation and assessment of soil erosion costs. Scientia Agricola, 70:209-216.

Wall, D., \& Nielsen, U. (2012). Biodiversity and ecosystem services: is it the same below ground. Nature Education Knowledge 3:8. 